\title{
Adaptation and Validation of the Muslim Medical Students Questionnaire (MMSQ) in the Indonesian Language
}

\author{
U Khoiriyah ${ }^{\mathrm{a}}$, D.P Wijaya ${ }^{\mathrm{a}}$, R Musa ${ }^{\mathrm{b}}$ \\ ${ }^{a}$ Medical Education Department, Faculty of Medicine Universitas Islam Indonesia \\ ${ }^{b}$ Department of Psychiatry, Kulliyyah of Medicine, International Islamic University Malaysia
}

\section{ABSTRACT}

INTRODUCTION: The Muslim Medical Students Questionnaire (MMSQ) is a self-assessment tool that was designed to measure student's Islamic competency in line with the implementation of the Islamic medical curriculum. For it to be applicable in Indonesia, this questionnaire needed to be translated and validated in the Indonesian language (Bahasa Indonesia). This study aimed to collect validity evidence of the Bahasa Indonesia version of MMSQ (BI-MMSQ). MATERIALS AND METHODS: The research process consisted of four stages: Forward and backward translation; Harmonization of the BI-MMSQ resulting from the initial stage; Pre-test of the BI-MMSQ among 30 clinical students, and finally construct validation among 225 clinical students. The completed questionnaires of 213 students were then analysed for their reliability and validity using exploratory factor analysis (EFA). RESULTS: The study showed that the scale had sufficient validity evidence; content, response process, and internal structure. The evidence of the internal structure of the tool is derived from the internal consistency (Cronbach's Alpha is 0.85) and also from the factor analysis. Most of the items had a factor loading value of $>0.3$, but it was suggested that some of those with a value of $<0.3$ should be rephrased to increase their quality. The Practice domain was the most stable sub-scale since most of the items contained high factor loadings. CONCLUSION: The BI-MMSQ had sufficient validity evidence and the internal structure may be improved by alteration of a few items.

KEYWORDS: Muslim, medical, adaptation, validation, Bahasa Indonesia

\section{INTRODUCTION}

Many Islamic medical faculties in Indonesia and other countries around the world have the vision of producing competent Muslim doctors. As such, certain efforts are taken by many Islamic medical faculties to achieve this; one such strategy being to design a specific curriculum. ${ }^{1}$ Consequently, a targeted assessment to measure whether students meet the learning objectives is required. It was considered that it might be possible to use some existing measurements to evaluate Muslim medical students'

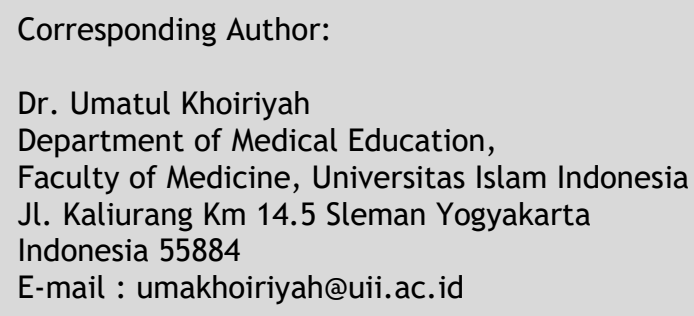

competency, including self- or teacher assessments, which could be formative or summative.

One of these existing measurements is the Muslim Medical Student Questionnaire (MMSQ). ${ }^{2}$ The MMSQ seems to be a comprehensive self-assessment questionnaire consisting of three domains (knowledge, attitude, and practice) with high relevancy to student competency. The Knowledge domain comprises 16 items; the Practice domain consists of 21 items; while the Attitude domain has eight items. The MMSQ provides good evidence of content and internal consistency. ${ }^{2}$ Although this tool has become available in the English language since it was first developed in Malaysia, to apply the questionnaire in Indonesia, 
translation and adaptation to Indonesian culture were required.

Currently, there is a paradigm-shifting in terms of validity framework. In the current validity framework, validity refers to the extent to which the evidence and theories supporting the interpretation of assessment results are in line with the underlying construct of the tool. The validity evidence consists of 5 types, which are: content evidence, response process, internal structure, correlation to other variables, and consequence. ${ }^{3,4}$ Content evidence refers to the linearity of the domain with the underlying concept of the tool and requires that the wording and format of the items be in line with the domain. ${ }^{4}$ Response process relates to the connection between the engagement and thought process of test-takers with the intended use of the test. Evidence of internal structure means the degree to which the relationship among items and test components confirms to the construct on which the proposed test score interpretations are based 5 and includes an evaluation of whether the internal consistency, generalisability, and factor structure are relevant to the underlying framework. ${ }^{6}$ Correlation to other variables is the relationship of the tool with the other variables measuring similar constructs. ${ }^{5}$ Lastly, evidence of the consequence of the tool refers to the intended or unintended effects of the tool. This study aimed to collect validity evidence of the Indonesian Version of MMSQ, especially content, response process, and internal structure evidence.

\section{METHODS AND RESULTS}

The study was conducted in the Faculty of Medicine of Universitas Islam Indonesia (FM UII) in the second half of 2018 and it has four stages, in accordance with the procedure for cross-cultural adaptation of questionnaires - see Figure 1. 7,8 The subjects were all students in the clinical phase. This study had been approved by the Ethics committee of FM UII. Written consents were obtained from the participants prior to the study together with a detailed explanation of the purpose of the study. The students were free to decline if they were not interested and not consented.

Before the students' recruitment, the translation process was conducted in two steps: forward and backward translations. In the first step, the original version of the MMSQ was translated into Bahasa Indonesia by two independent translators (a medical doctor and a medical expert). In the second step, this version was then retranslated into the English language by two new translators - also a medical doctor and a medical expert. The English questionnaire resulting from this stage was subsequently discussed with the test developer, (a senior consultant psychiatrist, IIUM) who developed MMSQ the original version, concerning whether it was significantly different from the original version. These processes produced some improvements and harmonization of the BI version. For instance, for item A2 (see Table 1), the word "update" was previously used in the BI version, but based on the input of the scale developer this word was not quite relevant to be used with the whole sentence, which was then revised. Overall, there was no change in terms of the number of the sub-scale and the number of items in each sub-scale of the BI-MMSQ compared to the original version. The results of this stage were then applied to Stage 3 (pretest).

A pre-test of the BI version was conducted on 30 clinical students.Although these students were not the same students used in the validation stage, they did have similar characteristics. The pre-test was intended to evaluate the clarity of the instruction and statement of each item in the questionnaire and also to assess the students' response processes. During the pre-test, students completed the MMSQ for around 15 minutes. Focus group discussion (FGD) was then conducted to explore students' experience in using the MMSQ. Students described that the instruction in the questionnaire was not very clear, especially in terms of their personal identity such as their previous education and their academic grade. The students also gave input that the instruction should be clearly stated as to their experience in the clinical phase (clerkship). In terms of the items, the students suggested that some items should be rephrased for clarification. Some items need to be adjusted to the Indonesian context. For instance, in item K13 the word "puasa" should be completed into "puasa sunnah". Another example is item P 21 where "short surah" in Indonesia is similar to "Juz 30 ( Juz 'amma)". The questionnaire was then revised and applied to the last stage. 


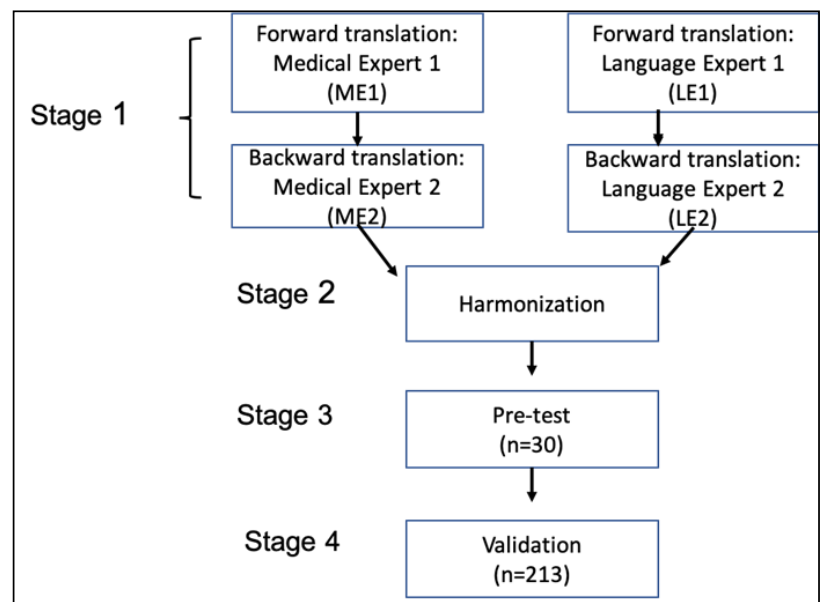

Figure 1: The adaptation and validation stages of the MMSQ

The last stage was the validation process, which aimed to collect evidence of internal structure validity. This was achieved through the distribution of an online questionnaire among clinical students who had at least one semester's experience in the clinical phase. Out of a total of 225 students, 213 completed the questionnaire and these responses were then analysed to assess the questionnaire's internal structure. Exploratory factor analysis using oblique rotation was applied to evaluate the domains underlying the tool and the quality of each item; the analysis was determined based on the value of the factor loading (which must be $>0.3$ ) and its relevancy to the concept or theory underlying the questionnaire.

The reliability analysis for each sub-scale showed that the Cronbach Alpha was more than 0.5. The Cronbach's alpha values were $0.72,0.59$, and 0.88 for the Attitude, Knowledge, and Practice subscales, respectively. The reliability score for all scales was also good at 0.85 . The results of the factor analysis are depicted in Table I.

The results (Table I) indicated that all items in the Attitude domain had a good factor loading ( $>0.3$ ); although these items were distributed into two factors. Item A7 had a factor loading of $>0.2$ in factors 1 and 2 . Furthermore, the data showed that items in the Knowledge domain also referred to factors 1 and 2. Out of 16 Knowledge items, 11 items had a factor loading of $>0.3$ while only one item (K4) had a factor loading of $<$ 0.2 , and item K16 did not have significant factor loading among the three factors. Nevertheless, most items in the Practice domain had good factor loading $(>0.3)$ and belonged to factor 1. Only factor-loading item P21 was less than 0.3 and belonged to factors 2 and 3 .

\section{DISCUSSION}

The study indicated that the process in Stage 1, which is the translation process from English to Bahasa Indonesia by medical experts, preserved the content of the questionnaire so that it remained similar to the original and unaltered from the developer's blueprint. ${ }^{6,7}$ The contribution by the language experts also revealed that each item in the BI-MMSQ was not different to the original. The harmonization process in Stage 2 was also part of content evidence. Feedback from the author of the original version MMSQ assured that each item in the BI version was in line with the blueprint and construct of the tool.

Research stage 3 provides evidence of the response process. In this stage, the adapted MMSQ was evaluated for its administration including time estimation, clarity of instruction, and organisation of the test format all of which were intended to minimise errors during tool implementation. ${ }^{6}$ This stage also explored students' thoughts when completing each item in the MMSS through FGD. The linearity between the test developer and test takers' thoughts is part of the response process evidence. $4,5,6$

The evidence of the tool's internal structure was collected by assessing the reliability and factor analyses, which is part of stage 4 of this research. ${ }^{4}$ The study demonstrated that the BI-MMSQ had good internal consistency and that the Cronbach's alpha values for the overall scale (0.8) and the two subscales (Attitude and Practice at 0.72 and 0.88 ) were good. Only the Knowledge subscale had a Cronbach's alpha value lower than 0.6 (0.59); however, this score was much better than that of the original version, which was only 0.13 .2 This result implied that the BI version of the MMSQ was appropriate for use in the Indonesian context.

The factor analysis revealed that all of the items in the Attitude domain had factor loadings of $>0.3$ (ranging between 0.31 and 0.47$)$. This means that these items had a fair agreement with their factors. Nonetheless, the data showed that all items in this domain belonged to factor 1 (the Knowledge domain) and factor 2 (the Practice domain) and that none of these items loaded to factor 3 (the Attitude domain). Items A1, A2, A5, and A6 were significantly relevant to the Knowledge domain. In the

IMJM Volume 20 No.2, Apr 2021 
Table I: Factor loadings of items in each domain

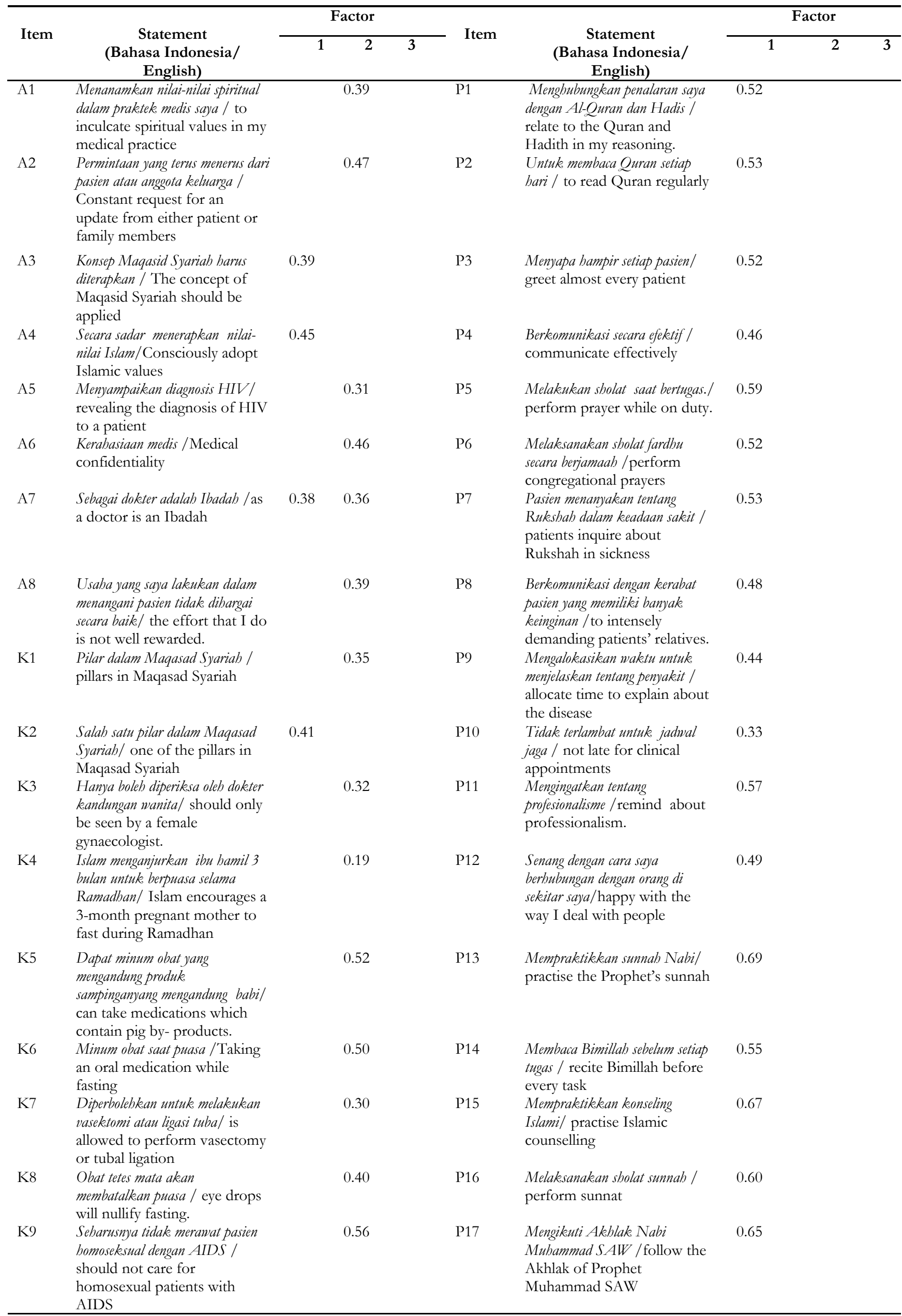

IMJM Volume 20 No.2, Apr 2021 
Con'

\begin{tabular}{|c|c|c|c|c|c|c|c|c|}
\hline K10 & $\begin{array}{l}\text { Sholat sunnah Dhuba /Sunnat } \\
\text { Dhuha prayer }\end{array}$ & & 0.73 & P18 & $\begin{array}{l}\text { Dapat mengenali Bid'ah dan } \\
\text { Khurafat / can recognize Bid'ah } \\
\text { and Khurafat }\end{array}$ & 0.60 & & \\
\hline K11 & $\begin{array}{l}\text { Konsep Ruksab diterapkan untuk } \\
\text { menyederbanakan pelaksanaan } \\
\text { ibadab/is applied to simplify } \\
\text { the performance of pravers }\end{array}$ & 0.27 & & P19 & $\begin{array}{l}\text { Dapat merawat Janazah / can } \\
\text { deal with a Janazah }\end{array}$ & 0.61 & & \\
\hline K12 & $\begin{array}{l}\text { Cara Tayamum/ Performance } \\
\text { of Tayammum }\end{array}$ & & 0.49 & P20 & $\begin{array}{l}\text { Mengingatkan pasien tentang } \\
\text { perlunya untuk melakukan } \\
\text { shalat / constantly remind } \\
\text { patients about the need to } \\
\text { perform prayers. }\end{array}$ & 0.69 & & \\
\hline K13 & $\begin{array}{l}\text { Disarankan pada hari Selasa dan } \\
\text { Jumat / is encouraged on } \\
\text { Tuesdays and Fridays }\end{array}$ & & 0.69 & P21 & $\begin{array}{l}\text { Menghafal juz } 30 \text { di Al Quran / } \\
\text { memorize common short } \\
\text { Surahs in Al Quran }\end{array}$ & & 0.27 & 0.26 \\
\hline K14 & $\begin{array}{l}\text { Juga dikenal sebagai surah } \\
\text { penyembuban./is also known as } \\
\text { a healing surah. }\end{array}$ & 0.24 & & & & & & \\
\hline K15 & $\begin{array}{l}\text { Juga dikenal sebagai Hadis Dhoif } \\
\text { (lemah)/is also known as } \\
\text { Hadith Dhoif (weak) }\end{array}$ & & 0.20 & & & & & \\
\hline K16 & $\begin{array}{l}\text { Dapat dilakukan pada operasi } \\
\text { bedah yang membutubkan waktu } \\
\text { yang lama/ is applicable when a } \\
\text { surgical operation involves } \\
\text { long hours. }\end{array}$ & & & & & & & \\
\hline
\end{tabular}

analysis, these items were found to be more appropriate to the Knowledge domain since it did not assess students' behaviour in the intended context or topic for instance, item A6 'Medical confidentiality is important in my practice' seemed to assess students' knowledge regarding the importance of medical confidentiality. On the other hand, items A3 and A4 were more relevant to factor 1 (the Practice domain) than factor 3 and students might have perceived these items as elements that should be applied in their daily practice. For instance, item A4 'I consciously adopt Islamic values when dealing with my patients' seemed to be in response to being asked whether they had employed Islamic values in their clinical practice. Interestingly, item A7 had good factor loadings in the Knowledge and Practice domains, and the item 'My work as a doctor is an Ibadah' is a concept of which students have the knowledge and which they practice during clinical learning or work.

The majority of items in the Knowledge domain had good factor loadings of $>0.4$, while six items (K1, K3, $\mathrm{K} 7, \mathrm{~K} 11, \mathrm{~K} 14$, and K15) had factor loadings of between 0.2 and 0.3 , and item K4 had a factor loading of $<0.2$ (0.19). In the item statement 'Islam encourages a 3month-pregnant mother to fast during Ramadhan provided there is no medical problem', the word 'encourage' makes this item multi-interpretational and students may or may not perceive it as being encouraged, so the answer could be 'Yes' or 'No'. Furthermore, the degree of medical problems could vary from one person to another and so there is no definitive answer to this statement. To increase the clarity, therefore, this item in the BI version needed to be rephrased. Item K16 (The use of Qada' in performing prayers is applicable when a surgical operation involves long hours) was the worst item in the Knowledge domain as it did not lead to all of the three factors and the data indicated that the majority of students' answers were false. They answered that qada' could be performed when the surgical operation took a long time. The students might have thought that qada' was similar to jama' (performing two prayers simultaneously); thus, this term needed to be substituted with other words or phrases that were more familiar and relevant to their understanding. Lastly, some items (K2, K11, and K14) did not connect to factor 2 (the Knowledge domain) but referred to factor 1 (the Practice domain). Items K2, K4 and K11 asked students about their knowledge of maqasid syariah, rukhsah and surah Al-fatihah. Not many students had good knowledge of these topics, which may explain why these items did not have good factor loadings for the Knowledge domain. The Islamic curriculum in FM UII places less emphasis on the recall of Islamic knowledge.

The results showed that most of the items in the Practice subscale were more stable than in the other 
subscales and had good factor loadings ( $>0.4)$. Only two items, P10 and P21, had factor loadings of less than 0.4. The Practice domain consisted of items that reflected students' behaviour when applying Islamic concepts and when they interacted with one another or with patients. For this reason, students did not have difficulty with the interpretation or remembering whether they had carried out the particular skill/ behaviour or not. On the other hand, the factor loading of item P10 'Saya tidak terlambat untuk jadwal jaga IGD, poli ataupun bangsal (I am not late for clinical appointments, such as clinics, wards, rounds, and meetings) was only 0.327 and not as good as the other factors - a result that might have been influenced by the research context. In the clinical phase of the FM UII, the clinical rotation was arranged based on each department, with time and learning variations in each. Not all departments had learning activities in their clinics, wards, and emergency rooms and this condition might have affected students' interpretation of the question. Furthermore, questionnaire items stating various contexts tend to be ambiguous with low internal consistency. 9,10 Item P21 had the worst factor loading of only 0.26 and belonged to factors 2 and 3, even though it had been expected that it would belong to factor 1 (the Practice domain). This finding was in line with the results from the factor analysis of the original version, showing that this item had high loading in the Knowledge domain. The developer indicated that this item receives greater emphasis in the memorizing of the Qur'an rather than in the practice of reciting it.2,11 Items P10 and P21 suggested that revision or rewording were required to improve their quality.

Compared to the original version, the results of the factor analysis of the BI version were not quite different from the original version. Some items in the Knowledge domain (K1, K5, K8, K12, K13, K14) had better loading factors than the original version.

Only 1 item in the BI version (K16/knowledge about qada') needs to be reconsidered or rephrased when it is applied in the Indonesian context. Most items in the affective domain of the BI version belonged to factor 2 . These results are different from the original version in that most of the Affective domain belonged to factor 3 . As discussed before, this might happen because in the Indonesian context these items were more appropriate to students' knowledge, not their behaviour. Lastly, the factor analysis of the items in the Practice domain of the BI version was not different from the original version. All of the items had good loading factors and belonged to factor 1 . This indicated that no contextual factor influencing students' thoughts in completing these items.

The selection of subjects who had experienced the context-specific to the questionnaire was one of the strengths of the research. Moreover, the contribution of the test developer was one of the positive aspects of this study, since it enabled an understanding of the underlying framework and nature of each item. In this study, the MMSQ was applied through an online questionnaire.

This online method assists the researchers to be able to collect the data in any situations such as the pandemic situation. However, this study also had limitations, such as its generalizability of the BI version to another medical faculty in Indonesia and that the participants were all from FM UII. Further studies with fixed methodologies and a broader range of participants would be necessary to gain greater validity evidence of the tool.

\section{CONCLUSION}

The Bahasa Indonesia version of the MMSQ demonstrated sufficient content and response process evidence. The process of validation also indicated that the BI version had a good internal structure. The BI version of the MMSQ had good internal consistency (Alpha $>0.8$ ) and the Practice domain was the most stable since only one item (P21) had a factor loading belonging to another domain. Some items in the Knowledge domain also had high factor loadings in other domains, whilst all items in the Attitude domain were more relevant to other domains. The recommendation is that some items with high factor loadings need to be rephrased to increase clarity and improve the internal structure of the tool. Furthermore, the revised BI version needs to be retested in further studies with robust methodologies to collect more evidence regarding its internal structure and other validity evidence such as correlation to other variables and consequence. 


\section{ACKNOWLEDGMENT}

The authors would like to thank all students at the Faculty of Medicine UII who participated in this study. The authors also would like to express our gratitude to the Dean of FM UII and FOKI (Forum Kedokteran Islam Indonesia) who facilitated this research collaboration.

\section{CONFLICT OF INTEREST}

The authors declare that there is no competing interest.

\section{REFERENCES}

1. Osman A. Integrating Islamic Value In Medical Teaching Curriculum: IIUM Experience. Bangladesh Journal of Medical Science. 2013;12(2):117-20. Available from: https://www.banglajol.info/ index.php/BJMS/article/view/14937

2. Musa R, Abdul Rani M, Che A A, Draman S. Development and validation of a new multidimensional questionnaire called Muslim Medical Student Questionnaire (MMSQ) among Malaysian undergraduates. International Medical Journal Malaysia 2013; Special issue(2): 97-106. Available from: https://journals.iium.edu.my/ kom/index.php/imjm/article/view/948

3. Kane MT. Current Concerns in Validity Theory. Journal of Educational Measurement. 2001;38(4):319-42.

4. Cook DA, Beckman TJ. Current Concepts in Validity and Reliability for Psychometric Instruments: Theory and Application. The American Journal of Medicine. 2006;119(2):166.e7-.e16.

5. American Psychological A, American Educational Research A, Joint Committee on Standards for E, Psychological T, National Council on Measurement in E, American Educational Research Association WDC, et al. Standards for educational and psychological testing. Washington, DC: American Educational Research Association; 1999.

6. Downing SM. Validity: on the meaningful interpretation of assessment data. Medical Education. 2003;37(9):830-7.

7. Beaton D, Bombardier C, Guillemin F, Ferraz M. Guideline for the process of cross-cultural adaptation of self-report measures. SPINE. 2000;25
(24):3186-91.

8. Gjersing L, JRM C, Claussen T. Cross-cultural adaptation of research instruments: language, setting, time and statistical considerations. BMC Medical Research Methodology. 2010; 10 (13). Available from: https:// bmcmedresmethodol.biomedcentral.com/ articles/10.1186/1471-2288-10-13

9. Streiner DL, Norman GR. Health Measurement Scales: A Practical Guide to Their Development and Use. 4th ed. Oxford: Oxford University Press; 2008.

10. Netemeyer RG, Bearden WO, Sharma S. Scaling procedures: Issues and application. London, United Kingdom: Sage Publications; 2003.

11. Nunnally JC, Bernstein IH. Psychometric Theory. 3rd ed. London: McGraw-Hill, Inc; 1994 